Microtus nivalis (MARTINs, 1842) (Rodentia) w Karpatach

Microtus nivalis (MARTINs, 1842) (Rodentia) в Kapnatax Microtus nivalis (MARTiNs, 1842) (Rodentia) in the

\title{
Carpathians
}

[With 5 textfigures]

HISTORY OF THE PROBLEM

In 1897 MoJsisovics voN MoJsvar mentions a specimen of snow vole which he saw in the Museum of Lwów. This specimen was presumably collected in the environs of Stanisławów. The author expresses his surprise because of this place of finding and states that the snow vole had not hitherto been reported from the Carpathians.

In 1908 G. S. MrLlee described a new species of vole, viz. Microtus ulpius MrLler from 18 specimens found at Ilatszeg in Transylvania by DANFORD. Miller places this new species in his subgenus Chionomys Mirler and shows its close relation to Mierotus nivalis (MARTINs).

In 1932, L. SAGAN found numerous specimens of the snow vole in Czarnohora (Eastern Carpathians). One of the specimens was sent to H. Pole, who published a note on it (1932). He stated that it is Chionomys nivalis (MARTINS), but that for the time being it was not possible to define to what subspecies it belonged. A year later J. FUDAKowskI wrote in detail on the voles of Czarnohora considering them as belonging to the species Chionomys ulpius MrLler. He mentioned as well that this species may be also found in the Tatras. LUBICZ-Nibzabitowski (1933, 1934) also wrote on Microtus ulpius MrLlen in the Czarnohora and published a drawing of its teeth from a specimen collected by L. SAGAN.

In $1934 \mathrm{~L}$. SAGAN gave further data on Chionomys ulpius MILleR from the Czarnohora. He also mentioned that he had found in the Tatras 
voles related to those of the Eastern Carpathians, but differing somewhat in the structure of the teeth and in eolour. He did not describe these specimens in detail.

In 1933, H. Schaefer found some subfossil material of small mammals in the Murańska Cave in the Tatra Mountains. In 1935 he published the results and stated the presence in the material of a new form of vole which hen named Mierotus (nivalis ?) mirhanreini SCHAEFER. He writes: „Der systematische Wert der Form ist noch unbestimmt; der Name ist zunächst nur ein Gebrauchsterminus". While his paper was in press Schaefer received from E. Bethenfalvy one complete specimen of Microtus mirhanreini SCHAEFER, but he did not deseribe it in detail.

J. EHIK obtained in 1942 two specimens of voles from the Rodna Mountains in the Eeastern Carpathians. On this basis he established a new species which he named Microtus radnensis EHIK. In this new species he also includes the voles from the Czarnohora, one specimen of which, collected by SAGAN, was in his possesion.

In $1949 \mathrm{~J}$. HANZAK and B. RosickY eollected in the Tatra Mountains a numerous series of voles belonging to the form Microtus mirhan. reini SCHAEFER, and were able therefore to describe this rodent in more detail than Schaffer. According to SchaEFER's suggestions, these authors deny the independence of the subgenus Chionomys MrLLer and consider Microtus mirhanreini ScHAEFER as a separate species, intermediate between Microtus nivalis (MARTINs) and Miorotus oeconomus (PALLAS). Simultaneously with the paper of the Czechoslovak authors, there was published that of ЕHIK based on the material sent him by them. Here the author is of different opinion regarding the systematic position of the high-mountain Carpathian voles. He thinks that they all belong to the species Mierotus nivalis (MARTINs) as three subspecies and are not closely related to Microtus oeconomus (PALLAs). S. I. OGNEv is of similar opinion as to the independence of $\boldsymbol{M}$. nivalis (MAR'INS) and M. oeconomus (PALLAS), he, however, includes all Eastern Carpathian voles in Microtus (Chionomys) nivalis ulpius MILler. In the work of B.S. Vinogradov and I. M. Gromov (1952) we also find a note that $M$. nivalis ulpius MrLleR occurs in the USRR in the Eastern Carpathians. In 1954 there was published K. A. TATARInov's work on the Eastern Carpathians snow vole. The author gives measurements of several specimens of this rodent and data on its biology. He states that only Miorotus nivalis ulpius MrLLen occurs in the whole region of the Carpathians. Finally in 1956 KRATOCHVIL published a paper with a characteristic of morphology of Microtus nivalis mirhanreini SCHAEFER population in Tatra Mountains in which some details of its biology are given.

Recent monographs of rodents give various opinions regarding the taxonomy of the Carpathian snow voles. J. R. Ellerman (1941) mentions from the Carpathians only Microtus ulpius MrLler. E. МоHR (1950) includes the snow voles of the Eastern Carpathians and Tatra 
Mountains in Chionomys nivalis ulpius ḾfrLere. J. R. ELLerman and T. C. S. Morrison-ScotT (1951) mention Mierotus nivalis ulpius MILler and $M$. nivalis radnensis EHIK. As it is clear from this review of the literature, we find a great divergence of opinion on the taxonomy of the Carpathian snow voles, even in the most recent works. Some authors consider them as only one form (MOHR, 1950; TATARINOv, 1954), some recognize two separate forms (Ellerman and Morrison-ScotT, 1951), and others three forms (HANZAK and RosickY, 1949; EHIK, 1949). Some seientists place all Carpathian forms in the species Miorotus nivalis Martins as subspecies (ЕнIK, 1949), others consider them as species, and Microtus mirhanreini SCHAEFER is supposed to be an intermediate form between M. nivalis (Martins) and M. oeconomus (Pallas), redueing thus to nothing the independence of the subgenus Chionomys MILLER.

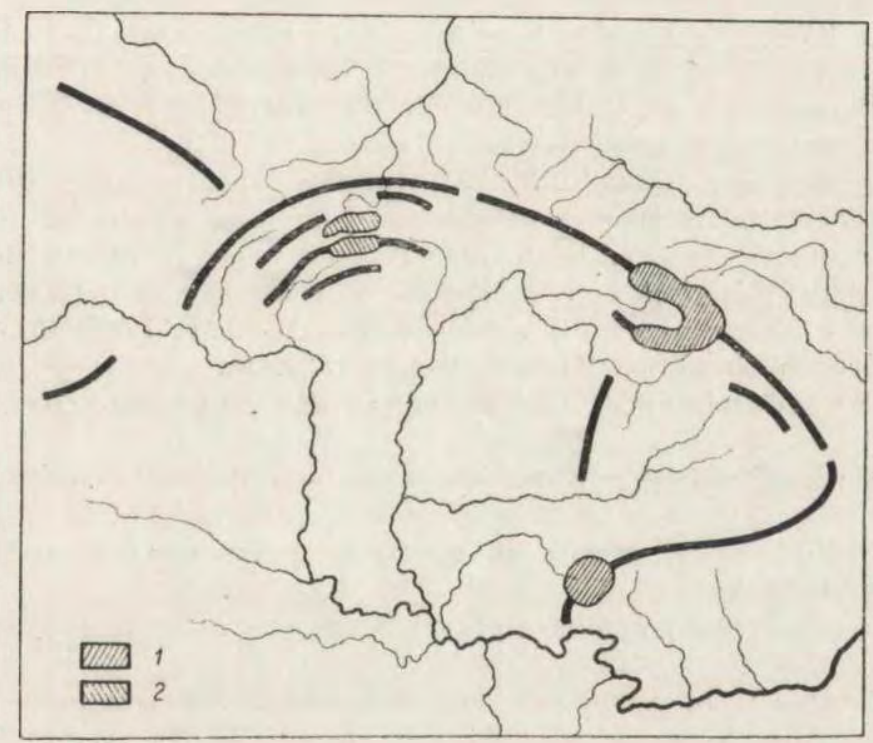

Fig. 1. Distribution of Mierotus nivalis (MARTINs) in the Carpathians.

1. M. nivalis ulpius MILleR, 2. M. nivalis mirhanreini SCHAEFer.

The aim of my research was to elear up the systematic position of the Carpathian voles of the group Mierotus nivalis (MARTINs). I based my investigations on the recent literature as well as on a relatively abundant material of voles from the Eastern Carpathians and the Tatras in the collection of the Cracow Branch of the Zoological Institute of the Polish Academy of Sciences. 
Microtus nivalis ulpius MHLLER, 1908

Microtus ulpius MILLER, 1908, 100-101.

Microtus ulpius MILLER, MILLER, 1912, 723.

Chionomys nivalis Martins, PoHLe, 1932.

Mierotus (Chionomys) ulpius Miller, LUbiCz-Niezabitowski, 1933, $68-69$, fig. 15 .

Ohionomys ulpius MILleR, FUdAKOWsKI, 1933.

Miorotus (Chionomys) ulpius Miller, Lubicz-NiezabitowsKi, 1934, 192.

Chionomys ulpius Mrller, SAGaN, 1934.

Chionomys ulpius MiLler, SAGAN, 1939.

Microtus ulpius Miller, Ellerman, 1941, 606.

Microtus (Chionomys) nivalis MARTINS, ЕнIK, 1941, 11.

Microtus (Chionomys) nivalis ulpius Miller, Winogradow and ARgYROPULO, 1941, 213.

Microtus (Chionomys) ulpius MrLLeR, Ентк, 1942, 18-23, fig. 5.

Miorotus (Chionomys) radnensis ЕнІк, 1942, 18-25, fig. 1-4, tab. 1; holotype: $ᄋ$ ad from the shores of Lake Mosolygo (1900 m. alt.) in the Rodna Mts., collected by Z. KASzaB in 1941; in the possession of the Budapest National Museum, no.4176/2.

Microtus radnensis EHIK, Енгк, 1949 [in the paper he states that he considers the form as a subspecies of Microtus nivalis (MaRtins)].

Microtus ulpius MrLler, EHIK, 1949 [in the paper he states that he considers this form as a subspecies of Microtus nivalis (MARTINs)].

Mierotus (Chionomys) nivalis ulpius MILleR, OGNev, 1950, 451-452.

Chionomys nivalis ulpius MILLER, MOHR, 1950, 18.

Miorotus nivalis ulpius MILler, Ellerman and MorRIson-Scott, 1951, 693.

Microtus nivalis radnensis EHIK, ElLERMAN and MoRrison-ScotT, 1951, 694.

Microtus (Ohionomys) nivalis ulpius Miller, Vinogradov and GroMov, 1952, 260.

Microtus (Chionomys) nivalis ulpius Miller, Tatarinov, 1954.

Holotype: o ad. (skull and skin) collected at Hatszeg in the Transylvanian Alps, Rumania, at 2000 feet, by C. G. Danrord, in the possession of the British Museum, no. 3, 2, 2, 48.

Figures: Niezabitowski-Lubicz, 1933, fig. 15 (teeth); SAGan, 1934, fig. 56 (photograph in toto); ЕнІк, 1942, figs. $1-4$, tab. 1 (drawing and photograph of the teeth of type and cotypes of Microtus radnensis EHIK), fig. 5 (drawing of teeth of topotype of Microtus ulpius MrLlen according to T. OLDFIELD's drawing from a specimen in the British Museum); TATARINov, 1954, fig. 1 (photograph in toto).

Geographical distribution: Transylvanian Alps (known only from the vicinity of Hatszeg; according to EHIK, 1942, it was probably not found in this locality but in the mountains surrounding it), Rodna Mountains, Marmaros Mountains, and Czarnohora. 
Material examined: 20 skins and 25 skulls from the Czarnohora and the Marmaros Mountains in the collection of the Zoological Institute of the Polish Academy of Sciences and 6 skins and 6 skulls from the Transylvanian Alps from the collection of the British Museum.

Diagnosis according to MrLLER, 1908: „Similar to Microtus nivalis but colour darker and tail usually brown above (often distinctly bicolor throughout); posterior border of palate with median ridge sharply defined; its width less than that of deep lateral pit; anterior loop of first molar as in $M$. nivalis aquitanicus". Miller writes further: ,This species is well differentiated from Microtus nivalis by the peculiar form of the palate and by the dark colour of the upperparts. Among the thirteen skins examined all show traces of brown on the upper surface of the tail, while in seven (including the type) the tail is distinctly bicolor throughout".

The morphology of this species, on the basis of the material which I brought together appears as follows.

Summer coat of adult specimens brown-grey on the dorsal side; along the middle of the back a little darker; sides clearer and gradually greying downwards. Ventral side grey, slightly suffused with brown. The transition of the colour of the back into that of the ventral side gradual. Colour similar to that of the specimens of Miorotus nivalis nivalis (MARTINs) from the Alps which I had for comparison. Tail distinctly bicoloured, dark above, elear-grey below. Young specimens differing distinctly in colour from the adults; they are smokegrey with indistinct, slight brown suffusion on the dorsal side; whiskers very long, reaching 4 or even $5 \mathrm{em}$, some of them fair, others dark brown.

Shape of palate similar to that of Microtus nivalis nivalis (MARTINS) but squama carinae medianae rather high, distinctly separated at the sides from the fossae laterales. Fossae laterales deep. Fossa interpterygoidea wide, its anterior edge of a rather variable outline, sometimes even and semicireular, sometimes with a slightly backwards protruding blunt projection of the squama carinae medianae. Width of the squama carinae medianae smaller than that of the fossae laterales. 
Microtus nivalis

\begin{tabular}{|c|c|c|c|c|}
\hline no. & 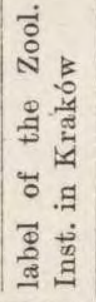 & locality & 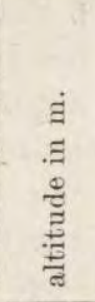 & date \\
\hline 1 & 394 & Czarnohora Mts., Breskuł & 1450 & 29 VII 1934 \\
\hline 2 & 395 & Czarnohora Mts., Pop Ivan & 1900 & 12 VIII 1935 \\
\hline 3 & 396 & Czarnohora Mts. & - & 4 VIII 1934 \\
\hline 4 & 399 & Czarnohora Mts., Zaroślak & 1500 & $29 \mathrm{VI} \quad 1934$ \\
\hline 5 & 401 & Marmaros Mts., Micheilecul & 1600 & 7 VIII 1935 \\
\hline 6 & 407 & Czarnohora Mts., Kocioł Breskulski & 1320 & $22 \mathrm{VI} \quad 1934$ \\
\hline 7 & 408 & Czarnohora Mts., Kocioł Koźmieski & 1650 & 23 VII 1935 \\
\hline 8 & 409 & Czarnohora Mtss., Kocioł Breskulski & 1350 & 28 VIII 1935 \\
\hline 9 & 410 & Czarnohora Mts., Kocioł Mały & - & 15 VIII 1935 \\
\hline 10 & 412 & Marmaros Mts. & 1600 & 7 VIII 1935 \\
\hline 11 & $(5)$ & Czarnohora Mts., Breskuł & 1450 & - \\
\hline 12 & (6) & Czarnohora Mts., Kocioł Breskulski & 1450 & 17 VII 1934 \\
\hline 13 & (7) & Czarnohora Mts., Breskuł & 1750 & 19 VII 1935 \\
\hline 14 & 398 & Czarnohora Mts., Kocioł Breskulski & 1650 & 10 VII 1934 \\
\hline 15 & 413 & Czarnohora Mts., Kocioł Breskulski & 1340 & 10 VII 1934 \\
\hline 16 & (1) & Czarnohora Mts., Breskuł & 1450 & 28 VII 1934 \\
\hline 17 & (2) & Czarnohora Mts., Smotryez & 1700 & - \\
\hline 18 & (3) & Czarnohora Mts., Kocioł Breskulski & 1450 & 10 VII 1934 \\
\hline 19 & $(8)$ & Czarnohora Mts., Kociol Mały & - & 15 VIII 1935 \\
\hline 20 & 397 & Czarnohora Mts., Kocioł Pożyżewski & 1500 & 14 VII 1934 \\
\hline 21 & 400 & Czarnohora Mts. & 1600 & 22 VII 1935 \\
\hline 22 & 402 & Czarnohora Mts., Breskuł & 1450 & $27 \mathrm{VI} \quad 1934$ \\
\hline 23 & 403 & Marmaros Mts., Micheilecul & 1600 & 7 VIII 1935 \\
\hline 24 & 404 & Czarnohora Mts., Pożyżewska & 1300 & 9 VIII 1935 \\
\hline 25 & 405 & Czarnohora Mts., Breskuł & 1450 & $27 \mathrm{VI} \quad 1934$ \\
\hline 26 & 406 & Czarnohora Mts., Kooioł Breskulski & 1340 & 10 VII 1934 \\
\hline 27 & 411 & Czarnohora Mts., Breskuł & 1450 & 29 VII 1934 \\
\hline 28 & (4) & Czarnohora Mts., Kociol Wielki & - & 17 VIII 1935 \\
\hline
\end{tabular}


ulpius MILLER, 1908

\begin{tabular}{|c|c|c|c|c|c|c|c|c|c|c|c|c|}
\hline $\begin{array}{l}\text { collected } \\
\text { by }\end{array}$ & 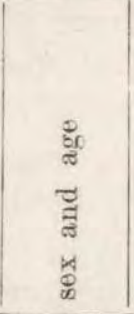 & 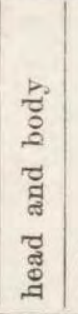 & శ్ & $\begin{array}{l}\overrightarrow{0} \\
\stackrel{\leftrightarrow}{0} \\
\ddot{\sharp}\end{array}$ & \% & 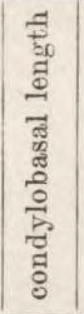 & 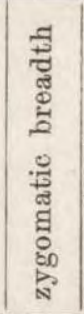 & 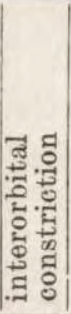 & 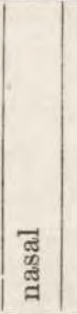 & 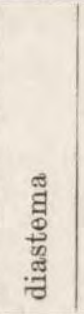 & 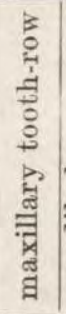 & 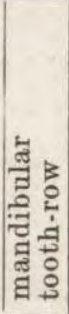 \\
\hline L. SAGAN & $q$ ad. & 121 & 72 & 21 & 16,5 & 29,3 & 16,6 & 4,5 & 8,8 & 9,7 & 6,8 & 6,9 \\
\hline L. $S_{A G A N}$ & 우 ad. & 121 & 68 & 21 & 17 & 29,8 & 17,1 & 4,5 & 8,7 & 9,8 & 6,8 & 7,0 \\
\hline L. SAGAN & ô ad. & 113 & 62 & 20 & 15 & 28,2 & 16,2 & 4,4 & 7,8 & 8,8 & 6,5 & 6,5 \\
\hline L. SAGAN & 우 ad. & 130 & 66 & 20 & 17 & 31,4 & 18,0 & 4,6 & 9,0 & 10,3 & 7,2 & 7,3 \\
\hline L. SAGAN & ㅇ ad. & 130 & 65 & 20 & 17 & 30,6 & 18,0 & 4,5 & 8,6 & 10,0 & 7,1 & 6,8 \\
\hline L. SAGAN & ㅇ ad. & 135 & 66 & 20 & 17 & 31,2 & 17,8 & 4,5 & 8,3 & 10,1 & 7,0 & 7,0 \\
\hline L. SAGAN & q ad. & 121 & 64 & 21 & 17 & 30,0 & 17,7 & 4,4 & 8,4 & 9,5 & - & - \\
\hline L. SAGAN & 우 ad. & 130 & 62 & 21 & 18,5 & 30,5 & 17,8 & 4,4 & 8,4 & 10,0 & 7,0 & 7,0 \\
\hline L. SAGAN & 우 ad. & 127 & 67 & 21 & 18 & 30,7 & 17,8 & 4,4 & 8,8 & 9,8 & 7,1 & 7,0 \\
\hline L. $S_{A G A N}$ & ㅇ ad. & 133 & 64 & 21 & 17 & 29,9 & 17,7 & 4,4 & 8,0 & 9,7 & 6,9 & 6,9 \\
\hline L. SAGAN & ad. & - & - & - & - & 30,3 & 17,3 & 4,4 & 8,5 & 9,8 & 7,0 & 7,0 \\
\hline L. SAGAN & ad. & 125 & 68 & 21 & 18 & 29,9 & 17,0 & 4,4 & 8,4 & 10,0 & 7,0 & 7,0 \\
\hline L. SAGAN & q ad. & 120 & 63 & 20 & 17,5 & 30,0 & 16,9 & 4,5 & 8,4 & 9,6 & 6,5 & 6,7 \\
\hline L. SAGAN & q subad. & 105 & 57 & 19,5 & 16,5 & 26,9 & 15,9 & 4,3 & 7,5 & 9,0 & 6,4 & 6,5 \\
\hline L. SAGAN & ㅇsubad. & 110 & 58 & 21 & 16 & - & - & - & - & - & $i-$ & - \\
\hline L. SAGAN & qsubad. & 108 & 61 & 20 & 17 & 27,7 & 16,5 & 4,5 & 7,8 & 8,9 & 6,5 & 6,5 \\
\hline L. SAGAN & ôsubad. & 107 & 56 & 20 & 15 & 26,7 & 16,5 & 4,5 & 7,2 & 8,4 & 6,6 & 6,7 \\
\hline L. SAGAN & †subad. & 110 & 58 & 21 & 16 & 27,8 & 16,4 & 4,5 & 8,0 & 8,6 & 6,8 & 6,7 \\
\hline L. SAGAN & qsubad. & 105 & 59 & 20 & 16 & 26,5 & 16,0 & 4,5 & 8,3 & 8,1 & 6,4 & 6,3 \\
\hline L. SAGAN & ㅇ juv. & 95 & 46 & 20 & 15 & 25,9 & 14,8 & 4,4 & 7,1 & 8,2 & 6,4 & 6,3 \\
\hline L. SAGAN & q juv. & 96 & 48 & 20 & 15 & 24,5 & 14,6 & 4,5 & 7,1 & 8,2 & 6,3 & 6,2 \\
\hline L. SAGAN & ô juv. & 94 & 47 & $20^{\circ}$ & 15,5 & 25,4 & 14,2 & 4,5 & $7,1 \mathrm{c}$ & ca 8,9 & 6,3 & 6,2 \\
\hline L. SAGAN & ô juv. & 100 & 56 & 21 & 16 & 25,8 & 14,9 & 4,4 & 7,6 & 8,1 & 6,4 & 6,4 \\
\hline J. FUDAKOW\&KI & ô juv. & 97 & 45 & 20 & 13 & - & - & 一 & - & - & - & - \\
\hline L. SAGAN & ơ juv. & 94 & 47 & 20 & 15,5 & - & - & - & - & - & - & - \\
\hline L. SAGAN & ơ juv. & 106 & 61 & 19 & 15 & 26,8 & 15,5 & 4,5 & 7,4 & 8,4 & 6,3 & 6,2 \\
\hline L. SAGAN & q juv. & 95 & 58 & 20 & 16 & 25,9 & 16,3 & 4,5 & 7,7 & 8,3 & 6,5 & 6,3 \\
\hline L. SAGAN & ơ juv. & 105 & 59 & 19 & 17 & 26,6 & 17,7 & 4,5 & 7,8 & 8,4 & 6,6 & 6,7 \\
\hline
\end{tabular}


Molar teeth of similar shape as in Microtus nivalis nivalis (MARTINS). First loop of first lower molar wide, variability of its shape small. Among the specimens which I have examined one shows a distinctly different structure of the second upper molar; its median enamel triangle is deeply incised from the inside. Several other specimens show in this place an indistinct depression in the enamel. Among the three specimens studied by EHIK one had a distinct incision

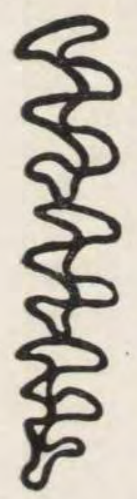

$m \times$

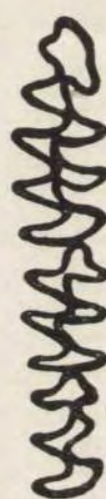

mo

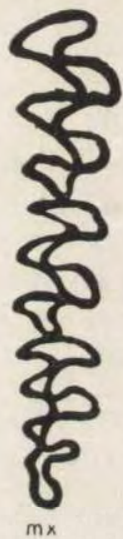

B

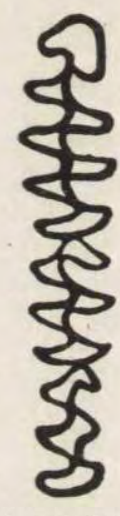

md

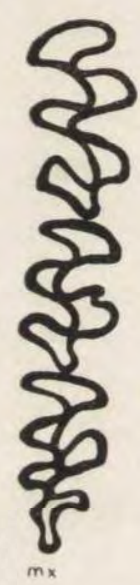

C

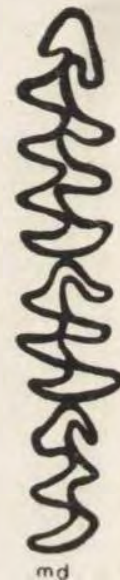

mo

A

Fig. 2. Molar teeth of three specimens of M. nivalis ulpius MrLLER from the Czarnohora. In specimen C a dental anomaly in the form of enamel incision in $\mathrm{m}^{2}$ is seen. $\mathrm{mx}$ - maxillar teeth, $\mathrm{md}$ - mandibular teeth.

of the enamel, in the second this feature was rather distinctly marked in one jaw, the third did not show this feature. The majority of specimens which I have examined showed no trace of any incision on the inside of the median triangle of the second upper molar tooth.

The measurements of the type are as follows. Head and body $-131 \mathrm{~mm}$., tail $-58 \mathrm{~mm}$., hind foot $-20 \mathrm{~mm}$., ear $17 \mathrm{~mm}$., condylobasal length of skull $30,4 \mathrm{~mm}$., zygomatic breadth $-18,0 \mathrm{~mm}$., interorbital constriction $-4,4 \mathrm{~mm}$., nasal length $-8,0 \mathrm{~mm}$., diastema $-9,2 \mathrm{~mm}$., length of the maxillary tooth-row $-7,2 \mathrm{~mm}$., length of the mandibular tooth-row $7,0 \mathrm{~mm}$. 
The measurements of the adult specimens which $\mathrm{I}$ have examined are as follows. Head and body $-120-135 \mathrm{~mm}$. (mean 125,5 mm.), tail $-62-72 \mathrm{~mm}$. (mean $65,6 \mathrm{~mm}$.), hind foot $-20-21 \mathrm{~mm}$. (mean 20,6), ear $-16,5-18,5 \mathrm{~mm}$. (mean $17,1 \mathrm{~mm}$.$) , condylobasal length -28,2-31,4 \mathrm{~mm}$. (mean $30,1 \mathrm{~mm}$.), zygomatic breadth $-16,1-18,0 \mathrm{~mm}$. (mean $17,4 \mathrm{~mm}$.), interorbital constriction $-4,4-4,6 \mathrm{~mm}$. (mean $4,5 \mathrm{~mm}$.), nasal lenght $-7,8-8,8 \mathrm{~mm}$. (mean $8,4 \mathrm{~mm}$.), diastema $-8,8-$ $10,3 \mathrm{~mm}$. (mean $9,8 \mathrm{~mm}$.), length of the maxillary toot-row $6,5-7,3 \mathrm{~mm}$. (mean $6,9 \mathrm{~mm}$.), length of the mandibular tooth-row $-6,5-7,3 \mathrm{~mm}$. (mean $6,9 \mathrm{~mm}$.). The ratio of the mean length of the tail to the mean length of the body is $52: 100$. The tail is thus a little longer than the half of the body. My material was not weighed. The weight of adult specimens, according to TATARINOV (1954), varies from 41 to $68 \mathrm{~g}$., the mean value being $51,2 \mathrm{~g}$.

Biology: The snow vole occurs in the Eastern Carpathians in the alpine meadows and Pinus mughus Scop. zone. It was generally collected in the valleys covered with seattered stones, with rich vegetation growing among them. The snow vole inhabits the regions at an altitude of $1300-1900 \mathrm{~m}$. SAGAN mentions the finding of a Microtus nivalis ulpius MrLLER in the alimentary canal of a viper at $1220 \mathrm{~m}$. In the forest zone, however, the voles were not collected.

Miorotus nivalis ulpius MHLER has probably two breeding periods in the year. According to TATARINOV (1954) SoKUR found four embryos $19 \mathrm{~mm}$.long in a female on May 25. Young and halfgrown specimens collected in July and August are from the spring brood. In the summer months both pregnant and nursing females are met with. The latest observation is dated August 28, when SAGAN found four embryos in a female. The number of embryos found in pregnant females varies from two to four.

Eastern Carpathian voles live in burrows among stones. Burrows dug in the turf are rarely met with. Near the entrances of the burrows remains of food are found; these indicate that the voles feed on Vaccinium myrtillus L., Gentiana ascle. piadea L., Cystopteris fragilis (L.) BERNH., Homogyne alpina (L.) CAss. and Aira L. sp. In the winter the voles dig burrows beneath the snow cover, very close to the surface of the soil. 
Microtus nivalis mirhanreini SCHAEFER, 1935

Mierotus (nivalis १) mirhanreini SCHAEFER, 1935, 560-561, fig. 12.

Microtus mirhanreini SCHAEFER, EHIK, 1941, 11.

Microtus mirhanreini SchaEfer, HaNzaK and Rosicky, 1949.

Microtus mirhanreini ScHAEFER, EHIK, 1949 [in his text he states that he considers this form as a subspecies of $M$. nivalis (MARTINs)]. Microtus mirhanreini SCHAEFER, Rosicky and KratochVIL, 1955. Microtus (Chionomys) nivalis mirhanreini Schaefer, KratochVIL, 1956.

Type: Schaefer (1935) does not say which of the 100 subfossil mandibles is to be considered as the type. HANZAK and RosickY give as a typical specimen ,in toto" a male from the Mięguszowiecka Valley in the Tatras $(1900 \mathrm{~m}$. alt.), collected by HaNzaK on Nov. 1, 1948. This specimen is in the collection of the Národní Museum in Praha.

Figures: Schaefer, 1935, fig. $12 \mathrm{~b}-\mathrm{h}$ (drawings of the enamel pattern of $\mathrm{m}_{1}$ ); HANZAK and ROSICKY, 1949, figs. 2, 3 (photograph of 6 specimens in toto), fig. 4 (drawings of the enamel pattern of $\mathrm{m}_{1}$ in 13 specimens), fig. 5 (drawing of the skull); EнIк, 1949, fig. 1 (photograph of the mandibular teeth); Kratochvil, 1956, figs. 4-9 (drawings of the enamel pattern of $\mathrm{m}^{1}, \mathrm{~m}^{2}$ and $\mathrm{m}^{3}$ ), figs. $16-17$ (2 specimens in toto).

Geographical distribution: Tatra and Lower Tatra Mountains, above the border of the forest zone.

Material examined: 51 skins, 43 skulls, 3 specimens in alcohol from the Tatra in the collection of the Cracow Branch of the Zoological Institute of the Polish Academy of Sciences.

The diagnosis according to ScHAEFER is as follows. ,Vertreter der ratticeps-nivalis-Gruppe. Beiden an Grösse gleich und mit beiden durch lange Übergansketten im typischen Merkmal des $m_{1}$ verbunden. Kennzeichen des Extrems: $m_{1}$ besitzt ausser aboraler Schleife 6 Dreiecke, aussen und innen je 3, von denen nur das vordere Paar unter sich geöfnet ist. Hierauf folgt eine abgetrennte Kappe, die etwas kleiner als bei nivalis ist". To this diagnosis, based only on the fossil material, HANZAK and ROSICKY add further features: ,On the whole it resembles in colouring the alpine fieldmice of the Alps, but is as a whole darker, dark gray with brown elements. Summer coat on the dorsal side nearly dark brown, far darker than the summer coat of $M$. nivalis. The winter coat is lighter, gray, the hair denser and longer $(15-18 \mathrm{~mm}$.) with whitish elements. The colouring of the ventral side is almost white 
without seasonal changes. In this feature it differs considerably from $M$. nivalis. Tail: upper side grayish brown, whitish below. One of our specimens in its winter coat has an almost unicolored whitish tail, which we attribute to ist considerable age. The difference between the light and dark hair is much more marked in the summer coat. All the measurements of the skull appear smaller in comparison with the other representatives of the group nivalis. But it was not possible to find essential differences in the details of its configuration".

The morphology of this species, on the basis of the material which I have examined, is as follows. Summer coat of adults grey on the dorsal side with slight light yellowish suffusion. It differs distinctly from Microtus nivalis ulpius MHLER and M. nivalis nivalis.(MARTINS), being more grey and without the dark brown shades occuring in those subspecies. Ventral part grey without any brown suffusion. Transition of the colour of the back into that of the ventral side gradual. Tail bicoloured; darker brownish above, silvery gray below. Young specimens smoke-grey, almost without brown shades. Whiskers very long, reaching $5 \mathrm{~cm}$, some fair, others dark brown.

Shape of palate similar to that of Microtus nivalis ulpius MHLER. It shows considerable variability. The squama carinae medianae high, distinctly separated at the sides from the deep fossae laterales. Fossa interpterygoidea wide, arched anteriorly.

Molar teeth. The characteristic feature of this subspecies is the great variability of the structure of the enamel loop of the first lower molar. In more or less half of the specimens in addition to the terminal loops in this tooth there occur six triangles and the front pair is connected by a wide transition. In the remaining specimens the sixth loop is more or less atrophied while the second triangle may be separated from the anterior terminal loop by a constriction (as in M. nivalis nivalis (MARTINS) or connected with it by a wide transition (as in M. oeconomus (PALLAS)). The latter type of $\mathrm{m}_{1}$ structure is the least frequent. The variability of $m_{1}$ concerns not only individual specimens but also the mandibular rami in the same individual. As a rule the loops of the first molar tooth are different on the left and right sides, and, sometimes, 
Table

M icrotus nivalis

\begin{tabular}{|c|c|c|c|c|c|c|}
\hline no. & 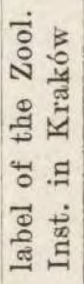 & locality & 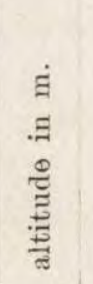 & date & & $\begin{array}{l}\text { collected } \\
\text { by }\end{array}$ \\
\hline 1 & 341 & Tatra Mts., Żółta Turnia & 17002 & $28 \mathrm{IX}$ & 1954 & S. SAGAN \\
\hline 2 & 345 & Tatra Mts., Liliowe & 1800 & $1 \mathrm{IX}$ & 1954 & S. SAGAN \\
\hline 3 & 346 & Tatra Mts., Beskid & 1800 & $1 \mathrm{IX}$ & 1954 & S. SAGAN \\
\hline 4 & 348 & Tatra Mts., Źółta Turnia & 1700 & $1 \mathrm{IX}$ & 1954 & S. SAGAN \\
\hline 5 & 350 & Tatra Mts., Liliowe & 1800 & $12 \mathrm{IX}$ & 1954 & S. SAGAN \\
\hline 6 & 352 & Tatra Mts., Liliowe & 1800 & $23 \mathrm{VII}$ & 1954 & S. SAGAN \\
\hline 7 & 354 & Tatra Mts., Hala Gąsienicowa & 1500 & 25 VII & 1954 & K. KOWALSKI \\
\hline 8 & 355 & $\begin{array}{l}\text { Tatra Mts., near Zadni Staw } \\
\text { Gagsienicowy }\end{array}$ & 1900 & 6 VIII & 1954 & K. KowALsKI \\
\hline 9 & 357 & $\begin{array}{l}\text { Tatra Mts. near Staw } \\
\text { Litworowy }\end{array}$ & 1650 & 9 VIII & 1954 & K. KoWALsKI \\
\hline 10 & 360 & Tatra Mts., Raptawicka Turnia & 1200 & $19 \mathrm{VIII}$ & 1954 & K. KowaLsKI \\
\hline 11 & 361 & Tatra Mts., Raptawieka Turnia & 1200 & $20 \mathrm{VIII}$ & 1954 & K. KowaLsKI \\
\hline 12 & 362 & Tatra Mts., Hala Gąsienicowa & 1550 & 31 VIII & 1954 & K. KoWALsKI \\
\hline 13 & 364 & Tatra Mts., Źółta Turnia & 1500 & $1 \mathrm{IX}$ & 1954 & K. KoWALsKI \\
\hline 14 & 365 & Tatra Mts., Żólta Turnia & 1500 & $1 \mathrm{IX}$ & 1954 & K. KoWALSKI \\
\hline 15 & 366 & Tatra Mts., Żółta Turnia & 1500 & $1 \mathrm{IX}$ & 1954 & K. KOWALSKI \\
\hline 16 & 368 & Tatra Mts., Granaty & 2000 & $1 \mathrm{IX}$ & 1054 & K. KowaLsKI \\
\hline 17 & 371 & Tatra Mts., near Zawrat & 2050 & $7 \mathrm{IX}$ & 1954 & K. KoWALsKI \\
\hline 18 & 372 & Tatra Mts., near Zawrat & 2050 & $7 \mathrm{IX}$ & 1954 & K. KoWALSKI \\
\hline 19 & 390 & Tatra Mts., near Morskie Oko & 1400 & 22 VIII & 1934 & L. SAGAN \\
\hline 20 & 392 & Tatra Mts., Źólta Turnia & 1600 & 6 VII & 1954 & S. SAGAN \\
\hline 21 & (9) & Tatra Mts., near Morskie Oko & 1400 & 17 VIII & 1934 & L. SAGAN \\
\hline 22 & 337 & Tatra Mts., Uhrocie Kasprowe & 1700 & 12 VIII & 1954 & S. SAGAN \\
\hline 23 & 338 & Tatra Mts., Uhrocie Kasprowe & 1700 & 12 VIII & 1954 & S. SAGAN \\
\hline 24 & 340 & Tatra Mts., Żółta Turnia & 1700 & 27 VIII & 1954 & S. SAGAN \\
\hline 25 & 342 & Tatra Mts., Żółta Turnia & 1700 & 28 VIII & 1954 & S. SAGAN \\
\hline 26 & 344 & Tatra Mts., Źółta Turnia & 1800 & $1 \mathrm{IX}$ & 1954 & S. SAGAN \\
\hline
\end{tabular}


II

mirhanreini SCHAEFER, 1935

\begin{tabular}{|c|c|c|c|c|c|c|c|c|c|c|c|c|}
\hline 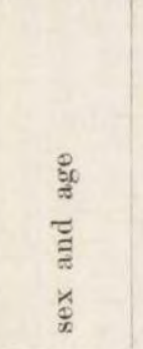 & 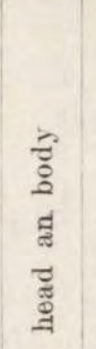 & ") & 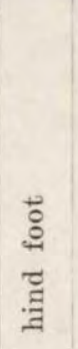 & స్ & 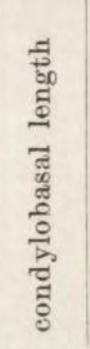 & 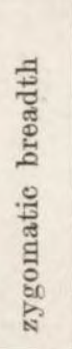 & 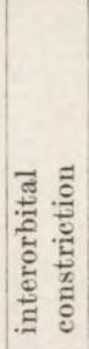 & 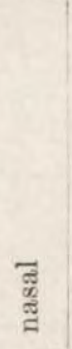 & 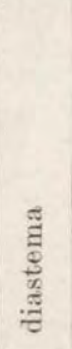 & 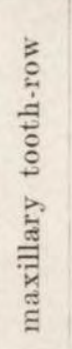 & 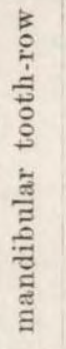 & $\begin{array}{l}\dot{s 0} \\
\Xi \\
\frac{\vec{b}}{00} \\
\equiv\end{array}$ \\
\hline 우 ad. & 123 & 55 & 21 & 15 & - & - & - & 6,9 & - & - & 6,6 & 45 \\
\hline ô ad. & 120 & 60 & 21 & 18 & 28,2 & 16,2 & 4,6 & 7,5 & 9,3 & 6,2 & 6,3 & 43 \\
\hline 우 ad. & 116 & 56 & 21 & 16 & - & - & 4,4 & 7,0 & 8,7 & 6,4 & 6,6 & 39 \\
\hline ot ad. & 134 & 61 & 21,5 & 18 & - & - & 4,5 & 8,3 & 9,8 & 6,4 & 6,5 & 50 \\
\hline 우 ad. & 133 & 62 & 19 & 17 & - & 17,0 & - & 8,2 & - & 6,5 & 6,7 & - \\
\hline 우 ad. & 128,5 & 56,5 & 25 & 17 & - & - & - & - & - & - & - & - \\
\hline$\hat{\sigma}$ ad. & 122 & 54 & 21 & 16. & 30,1 & 17,1 & 4,4 & 8,9 & 9,8 & 6,4 & 6,6 & - \\
\hline ơ ad. & 116 & 60 & 20 & 16 & - & 16,2 & - & - & - & 6,5 & 6,4 & 48 \\
\hline ô ad. & 140 & 61 & 20 & 18 & 30,9 & 17,3 & 4,3 & 8,2 & 10,0 & 7,0 & 7,1 & 60 \\
\hline 우 ad. & 124 & 64 & 22 & 19 & - & - & 4,4 & - & - & 6,7 & 7,1 & - \\
\hline 우 ad. & 119 & 52 & 18 & 16 & - & - & 4,5 & - & - & 5,9 & 6,1 & - \\
\hline 우 ad. & 109 & 55 & 20 & 16 & 27,8 & 16,0 & 4,4 & 7,6 & 8,4 & 6,3 & 6,4 & 42,5 \\
\hline 우 ad. & 122 & 60 & 19 & 16 & - & - & - & 7,8 & - & 6,9 & 6,8 & 49,5 \\
\hline ㅇ ad. & 116 & 54 & 20 & 16 & - & - & - & 7,8 & - & 6,8 & 6,5 & 51,5 \\
\hline 우 ad. & 106 & 51 & 20,5 & 16 & - & - & - & 7,5 & - & 6,5 & 8,8 & 40 \\
\hline 우 ad. & 112 & 57 & 19,5 & 15,5 & - & - & - & 7,6 & 8,6 & 6,1 & 6,1 & 38 \\
\hline ot ad. & 119 & 56 & 20 & 16,5 & - & - & - & 7,5 & 9,4 & 6,7 & 6,6 & 38,5 \\
\hline q ad. & 112 & 67 & 19 & 17 & - & - & - & - & - & - & 6,4 & 40,5 \\
\hline 우 ad & 118 & 64,5 & 20 & 16 & - & - & - & - & - & - & - & - \\
\hline ô ad. & 129 & 56 & 20 & 18 & 27,6 & - & 4,5 & 7,5 & 8,7 & 6,4 & - & - \\
\hline- & - & - & - & - & - & - & 4,1 & 8,0 & 9,0 & 6,4 & 6,5 & - \\
\hline 오 subad. & 116 & 60 & 20 & 16 & - & - & - & - & - & - & - & - \\
\hline 우 subad. & 107 & 60 & 20 & 16 & - & - & - & - & - & - & - & - \\
\hline 우 subad. & 107 & 53 & 21 & 14 & - & 15,4 & 4,4 & - & - & 6,4 & 6,4 & 35 \\
\hline 오 subad. & 112 & 52 & 19,5 & 15 & 27,8 & 16,5 & ca 4,5 & 7,1 & 9,1 & 6,6 & 6,7 & - \\
\hline ㅇ subad. & 114 & 51 & 20 & 16 & 26,4 & 15,3 & 4,3 & 7,0 & 8,2 & 6,1 & 6,2 & 38 \\
\hline
\end{tabular}


Continuation of

\begin{tabular}{|c|c|c|c|c|c|c|}
\hline no. & 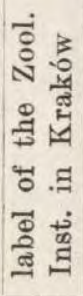 & locality & 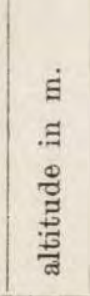 & dat & & collected by \\
\hline 27 & 351 & $\begin{array}{l}\text { Tatra Mts., Uhrocie Kasprowe } \\
\text { Tatra Mts., near Staw }\end{array}$ & 1800 & $12 \mathrm{IX}$ & 1954 & S. SAGAN \\
\hline 28 & 358 & Litworowy & 1650 & $9 \mathrm{VIII}$ & I 1954 & K. KowALSKI \\
\hline 29 & 369 & Tatra Mts., Żólta Tưrnia & 1500 & 3 IX & 1954 & K. KOWALSKI \\
\hline 30 & 370 & Tatra Mts., Żólta Turnia & 1500 & 3 IX & 1954 & K. KOWALSKI \\
\hline 31 & 383 & Tatra Mts., Uhrocie Kasprow & 1800 & 24 IX & 1953 & S. SAGAN \\
\hline 32 & 384 & $\begin{array}{l}\text { Tatra Mts., near Czarny Staw } \\
\text { Gąsienicowy }\end{array}$ & 1650 & 17 VIII & 1934 & L. SAGAN \\
\hline 33 & 385 & Tatra Mts., Hala Gąsienicowa & 1620 & 17 VIII & I 1934 & L. $S_{\triangle G A N}$ \\
\hline 34 & 387 & Tatra Mts., near Morskie Oko & 1400 & 23 VIII & 1934 & L. SAGAN \\
\hline 35 & 388 & Tatra Mts., near Morskie Oko & 1400 & 17 VIII & 1934 & L. SAGAN \\
\hline 36 & 389 & Tatra Mts., near Morskie Oko & 1400 & 23 VIII & 1934 & L. SAGAN \\
\hline 37 & 391 & Tatra Mts., near Morskie Oko & 1400 & 17 VIII & 1934 & L. SAGAN \\
\hline 38 & (10) & Tatra Mts., near Morskie Oko & 1400 & 23 VIII & 1934 & L. SAGAN \\
\hline 39 & 334 & Tatra Mts., Uhroeie Kasprowe & 1800 & $7 \mathrm{VIII}$ & 1954 & S. SAGAN \\
\hline 40 & 335 & Tatra Mts., Uhrocie Kasprowe & 1800 & $7 \mathrm{VIII}$ & 1954 & S. SAGAN \\
\hline 41 & 336 & Tatra Mts., Uhrocie Kasprowe & 1800 & 7 VIII & {$[1954$} & S. SAGAN \\
\hline 42 & 343 & Tatra Mts., Żólta Turnia & 1700 & 28 VIII & 1954 & S. SAGAN \\
\hline 43 & 347 & Tatra Mts., Beskid & 1800 & $1 \mathrm{IX}$ & 1954 & S. SAGAN \\
\hline 44 & 349 & Tatra Mts., Źólta Turnia & 1700 & $12 \mathrm{IX}$ & 1954 & S. SAGAN \\
\hline 45 & 353 & $\begin{array}{l}\text { Tatra Mts., Hala Gasienicowa } \\
\text { Tatra Mts., near Zadni Staw }\end{array}$ & 1450 & $23 \mathrm{VII}$ & 1954 & K. KOWALSKI \\
\hline 46 & 356 & $\begin{array}{l}\text { Gąsienicowy } \\
\text { Tatra Mts., near Staw }\end{array}$ & 1900 & 6 VIII & 1954 & K. Kowalski \\
\hline 47 & 359 & Litworowy & 1650 & $9 \mathrm{VIII}$ & 1954 & K. KOWALSKI \\
\hline 48 & 363 & Tatra Mts., Hala Gąsienicowa & 1550 & 31 VIII & 1954 & K. Kowalski \\
\hline 49 & 367 & Tatra Mts., Żółta Turnia & 1500 & $1 \mathrm{IX}$ & 1954 & K. KowALSKI \\
\hline 50 & 373 & Tatra Mts., Żółta Turnia & 1600 & $5 \mathrm{VII}$ & 1954 & S. SAGAN \\
\hline 51 & 380 & Tatra Mts., Uhrocie Kasprowe & 1750 & $7 \mathrm{XI}$ & 1953 & S. SAGAN \\
\hline 52 & 386 & Tatra Mts., near Morskie Oko & 1400 & 26 VIII & {$[1934$} & L. SAGAN \\
\hline 53 & 393 & Tatra Mts., Liliowe & 1700 & 26 VII & 1954 & S. SAGAN \\
\hline
\end{tabular}


table II

\begin{tabular}{|c|c|c|c|c|c|c|c|c|c|c|c|c|}
\hline 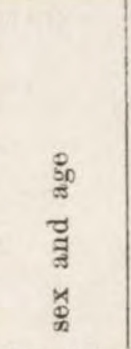 & 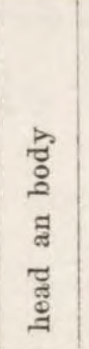 & స్తึ & $\begin{array}{l}\overrightarrow{0} \\
\stackrel{\leftrightarrow}{0} \\
\vec{\Xi} \\
\ddot{g}\end{array}$ & స్ & 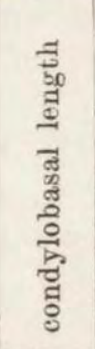 & 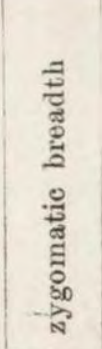 & 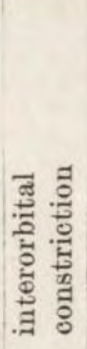 & $\begin{array}{l}\text { 烝 } \\
\text { 心 }\end{array}$ & 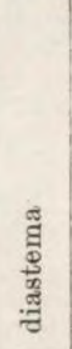 & 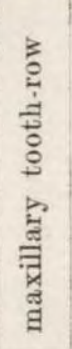 & 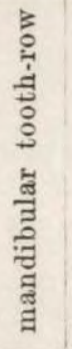 & $\begin{array}{l}\dot{0} \\
.7 \\
+\overrightarrow{1} \\
.00 \\
0 \\
0\end{array}$ \\
\hline ơ subad. & 121 & 54 & 19 & 15 & - & - & 4,4 & 7,5 & 8,6 & 6,0 & 6,3 & - \\
\hline ô subad. & 113 & 44 & 20 & 15 & 25,8 & 14,9 & 4,5 & 7,3 & 8,1 & 5,9 & 5,9 & 31,5 \\
\hline q subad. & 117 & 48 & 20 & 15 & - & - & 4,3 & - & 8,1 & 6,1 & 6,3 & 33,5 \\
\hline \& subad. & 107 & 47 & 20 & 16 & - & ca 15,7 & 4,5 & - & - & 6,4 & 6,4 & 31,5 \\
\hline$q$ subad. & 109 & 66 & 21 & 19 & 27,7 & 16,7 & 4,3 & 7,6 & 8,6 & 6,1 & 6,0 & - \\
\hline to subad. & 1045 & 59 & 19 & 16,5 & 25,7 & 15,2 & 4,3 & 7,4 & 8,1 & 5,9 & 6,1 & - \\
\hline ơ subad. & 103 & 58 & 19 & 16,5 & 27,7 & - & 4,1 & 7,5 & 8,8 & 6,3 & 6,2 & - \\
\hline o+ subad. & 99 & 48 & 18 & 14,5 & 26,1 & 14,8 & 4,5 & 7,2 & 8,3 & 6,3 & 6,2 & - \\
\hline q subad. & 103 & 53 & 18 & 16 & 27,3 & 16,1 & 4,4 & 7,8 & 8,8 & 6,1 & 6,2 & - \\
\hline \& subad. & 100 & 47 & 20 & 16 & 25,6 & 14,4 & 4,5 & - & 7,8 & 5,9 & 6,2 & - \\
\hline 우 subad. & 101 & 52,5 & 19,5 & 16 & - & - & - & - & - & - & - & - \\
\hline q subad. & 109 & 66 & 20 & 16 & 27,3 & 16,1 & 4,3 & 7,4 & 8,8 & 6,2 & 6,5 & - \\
\hline ㅇ juv. & 107 & 48 & 20 & 16 & - & - & - & - & - & - & - & - \\
\hline o juv. & 120 & 55 & 20 & 15 & $\pm 25,2$ & 14,5 & $+4,3$ & 6,9 & - & 5,9 & 6,1 & - \\
\hline † juv. & 107 & 50 & 20 & 15 & - & $1-$ & - & - & - & - & - & - \\
\hline ㅇ juv. & 98 & 43 & 20 & 13,5 & - & ca 14,0 & 4,4 & - & - & 5,9 & 5,7 & - \\
\hline ô juv. & 104 & 47 & 20 & 16,5 & 25,7 & - & - & - & 8,5 & 6,0 & 6,1 & 30 \\
\hline q juv. & 110 & 50 & 19 & 13 & - & - & 4,4 & 7,5 & 8,1 & 6,2 & 6,3 & - \\
\hline đo juv. & 89 & 34 & 19 & 18 & - & - & 4,5 & 7,2 & 7,0 & 5,8 & 5,8 & - \\
\hline ठ઼ juv. & 94 & 41 & 18 & 13 & 24,1 & 13,6 & 4,6 & 6,8 & 7,6 & 5,7 & 5,7 & 18,5 \\
\hline ơ juv. & 99 & 42 & 17 & 15 & - & - & 4,5 & 6,8 & 7,7 & 5,9 & 6,4 & 27 \\
\hline ô juv.. & 93 & 46 & 20 & 15 & - & - & - & os 6,9 & - & 5,9 & 6,0 & 26,7 \\
\hline ơ juv. & 94 & 38 & 19 & 14 & - & - & - & 6,8 & - & - & 5,9 & 21 \\
\hline q juv. & 104,5 & 46,5 & 19 & 15 & - & - & - & - & - & - & - & - \\
\hline q juv. & 124 & 46 & 22 & $19(?)$ & - & - & - & - & - & - & - & - \\
\hline ơ juv. & 91 & 44 & 18 & 14 & 23,7 & 13,7 & 4,2 & 6,3 & 7,8 & 5,7 & 6,0 & - \\
\hline ㅇ juv. & 107,5 & 44,5 & 20 & 15 & - & - & - & - & - & - & - & - \\
\hline
\end{tabular}


there is on one side a structure typical of $M$. nivalis nivalis (MARTINS) while on the other of $M$. nivalis mirhanreini SCHAEFER.

The remaining molar teeth do not show such extensive variability. In $\mathrm{m}^{2}$ there is usually no trace of an incision on the second internal loop. Only in one of the specimens examined [fig. 3] we see on this loop, in the right as well as in the left row of teeth, very distinct and deep incisions, as in several specimens of $M$. nivalis ulpius MTLLER.
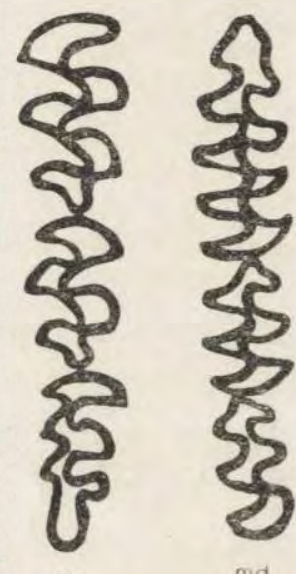

A

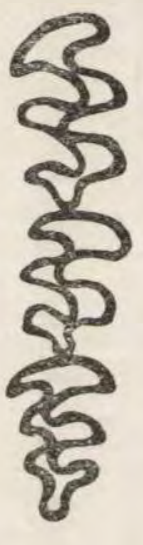

$m x$

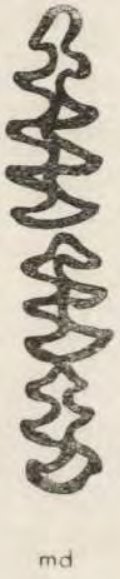

B

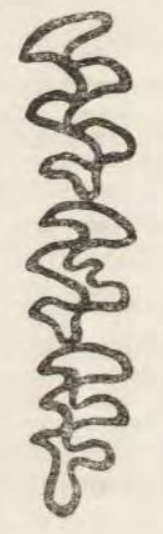

$m \times$

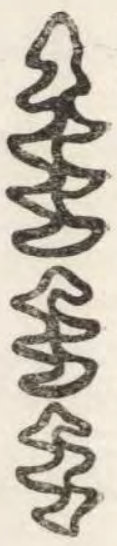

md

C.

Fig. 3. Molar teeth of three speoimens of M. nivalis mirhanreini ScHaEFEn from the Tatras. In specimen $\mathrm{C}$ a dental anomaly in the form of enamel incision in $\mathrm{m}^{2}$ is seen. $\mathrm{mx}$ - maxillar teeth, $\mathrm{md}$ - mandibular teeth.

The measurements of the type represented by the subfossil mandible are not known. The specimen chosen by HANZAK and ROSICKY as typical , in toto" has the following measurements: Head and body $-130 \mathrm{~mm}$., tail $-55 \mathrm{~mm}$., hind foot $-23 \mathrm{~mm}$., condylobasal lenght $-28,6 \mathrm{~mm}$., zygomatic breadth $-16,8 \mathrm{~mm}$., interorbital constriction $-4,7 \mathrm{~mm}$., the length of the maxillary and mandibular rows of teeth each $-5,3 \mathrm{~mm}$.

The measurements of the adult apecimens which I have examined are as follows. Head and body $-106-140 \mathrm{~mm}$. (mean 120,8 mm.), tail - 51-67 mm. (mean $58,2 \mathrm{~mm}$.), hind 
foot $-18-22 \mathrm{~mm}$. (mean 20,3 $\mathrm{mm}$.), ear $-15,5-19 \mathrm{~mm}$. (mean $16,7 \mathrm{~mm}$.), condylobasal length $-27,6-30,9 \mathrm{~mm}$. (mean $28,9 \mathrm{~mm}$.), zygomatic breadth $-16-17,3 \mathrm{~mm}$. (mean 16,6 mm.), interorbital constriction - 4,3-4,6 mm. (mean 4,4 mm.), diastema $-8,4-10 \mathrm{~mm}$. (mean $9,2 \mathrm{~mm}$.), length of maxillary

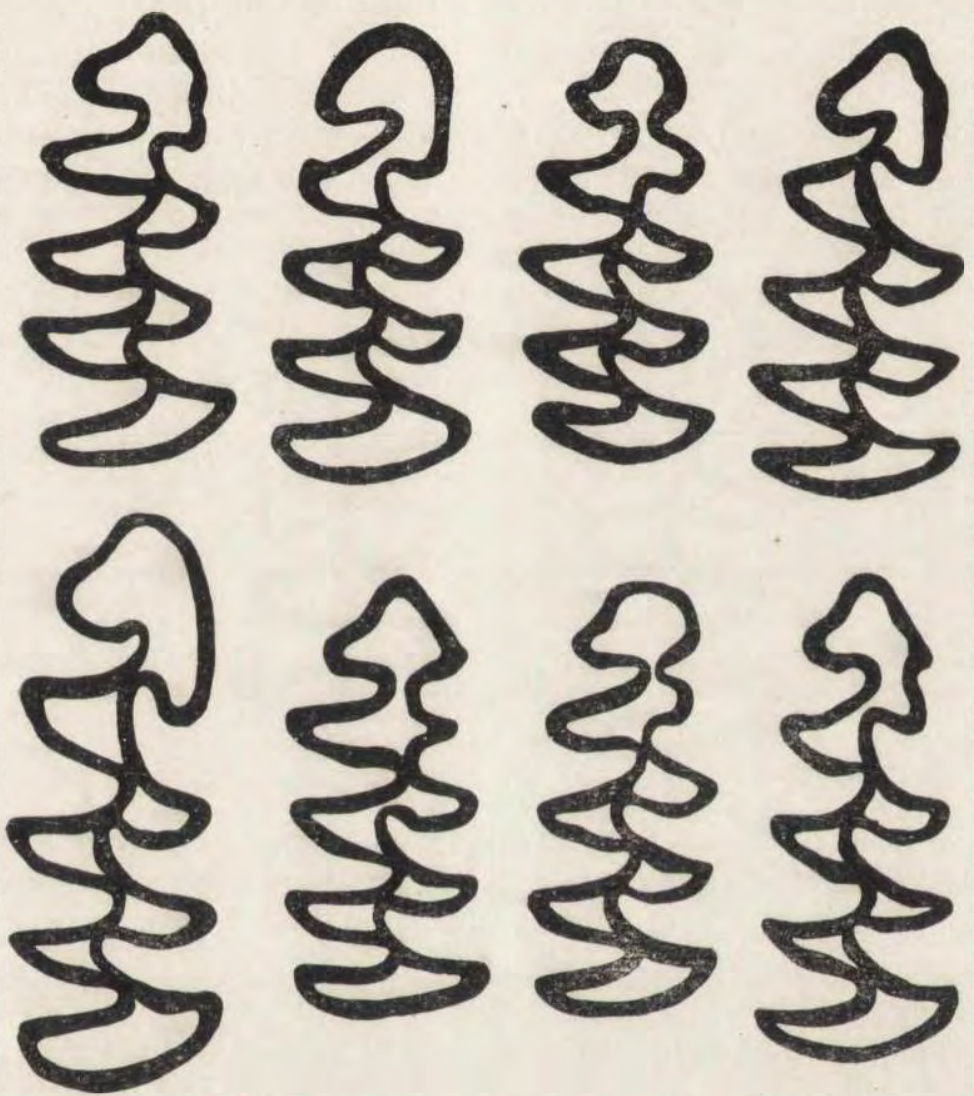

Fig. 4. Variability of enamel pattern of the first lower molar in M. nivalis mirhanreini SCHAEFER from the Tatras.

tooth-row $-5,9-7,0 \mathrm{~mm}$. (mean $6,5 \mathrm{~mm}$.), length of mandibular tooth-row $-6,1-7,1 \mathrm{~mm}$. (mean $6,6 \mathrm{~mm}$.). The ratio of the mean length of the tail to that of the body is $48: 100$, the tail is thus a little shorter than half the body length. The weight of the adult specimens varies from 38 to $60 \mathrm{~g}$.; the mean value is $45,0 \mathrm{~g}$. 
Biology: The Tatra snow vole is found in the subalpine and alpine zone of the Tatras and Lower Tatras. In the Tatras I have never found it in the dense forest zone, althought in not forested places such as steeps rocks and alpine meadows it occurs at much lower altitudes. The lowest places where it was collected are situated at an altitude of $1200 \mathrm{~m}$. Above this, the snow vole reaches the highest Tatra summits. The highest position where I have observed it lies at $2250 \mathrm{~m}$. ROSICKY and KRATOCHVIL (1955) write that voles were observed on the highest peak of the Tatras, the Gerlach $(2663 \mathrm{~m})$.
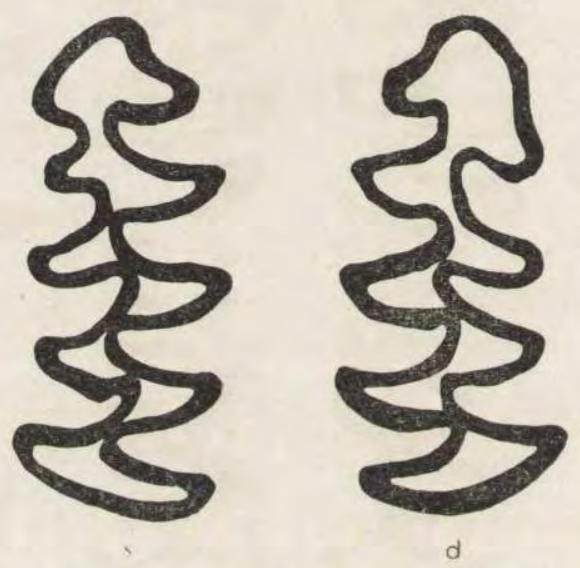

Fig. 5. Asymetry of enamel pattern of the first lower molar in M. nivalis mirhanreini SCHAEFER from the Tatras. $\mathrm{s}-\mathrm{m}_{1}$ of left mandibular ramus, $d-$ of right one in the same specimen.

The Tatra snow vole is most numerous in the zone of Pinus mughus Scop. Above this, it usually appears in the rich alpine valleys regions. According to HANZAK and RosickY's supposition, which are not, however, based on. any immediate proof, the voles migrate in winter from the higher regions to the zone of Pinus mughus Scop.

The Tatra snow vole is active mainly in the night, when it is most often caught in traps. It may, however, also be observed on the surface of the ground during day-time.

Observations hitherto made do not allow to establish the number of breeding periods. In July and August I observed, 
besides adults, numerous young and half-grown specimens. I did not collect pregnant females at that time, but the adult males had very well developed testicles. The Tatra snow voles generally hide in crevices and burrows between stones and roots of Pinus mughus ScoP. I have not found burrows dug by them. Twigs of Vaccinium myrtillus L. are often drawn into the entries to their hideouts. This is presumably the main food of the vole in the zone of Pinus mughus Scop. In the stomachs of specimens cought I have always found a well ground pulp of vegetable tissues.

\section{GENERAL REMARKS}

In the Carpathians there appear to occur two distinctly different forms of the snow vole, Microtus nivalis ulpius MILLER and Microtus nivalis mirhanrtini SCHAEFER. They differ from each other by the colour, which in the Tatra form is of a greyer shade and completely larks the brown shades on the ventral side, while the Eastern Carpathian form is distinctly brown with a slight brown suffusion on the ventral side. The Tatra forms is characterized also by the unusual variability of $m_{1}$, which in at least half of the specimens shows the presence of at least traces of the sixth enamel triangle between the two terminal lopps. Finally the Tatra snow vole is smaller than the Eastern Carpathian. Althout the limits of variability overlap, the means of all total measurements of specimens as well as of the skulls, are higher in the series of voles from the Czarnohora. All these facts justify completely the distinction of the Eastern Carpathian and Tatra voles as two separate subspecies.

Beside M. nivalis ulpius MHLER and M. nivalis mirhanreini SCHAEFER one more form of snow vole from the Carpathians, viz. M radnensis ЕHu has been described. The main diagnostic feature of this form was supposed to be the presence of an incision on the inner enamel loop of $\mathrm{m}^{2}$. Among the three specimens upon which ЕHIK based the description of M. radnensis ЕHIK one showe this feature distinctly, in the second it was less distinct and risible only on one side and in the third it was completely absent. As the examination of a larger series of specimens showed, the incision of the inner 
enamel loop of $\mathrm{m}^{2}$ is a rather rare anomaly in some individuals and is not a feature shown by the whole population investigated. This anomaly was found also in one specimen of $M$. nivalis mirhanreini SCHAEFER. This feature therefore cannot serve to distinguish $M$. radnensis Eнтк from $M$. nivalis $u l$ pius MrLLeR. The remaining differences between these two forms which Еншк points out arise from his erroneous interpretation of MrLLER's diagnosis. EHIK had no specimens of $M$. nivalis ulpius MrLLeR but only the description at his disposal. In his diagnosis MuLLeR (1908) writes ,pposterior border of palate with median ridge sharply defined". As is clear from EHIK's text, he understands ",sharply defined" as ,spitzwinkelig vorspringend" and because of this misunderstanding he thinks the palate in the two forms to be of different structure.

A comparison of the series of specimens from the Marmaros Mountains and the Czarnohora with the 6 specimens from the Transylvanian Alps forming a part of the series upon which MHLEe based his description of the species Microtus ulpius MriL., lent by the British Museum, showed that they belong to the same subspecies. The colour and dentition do not differ in the specimens from the two regions, and the structure of the palate, rather variable individually, varies within almost the same limits. We see therefore that there are no reasons to distinguish a third subspecies of the Carpathian snow voles. The Northern and Southern parts of the Eastern Carpathians are inhabited by the same subspecies, viz. Microtus nivalis ulpius MHLER, 1908.

As mentioned, the structure of $\mathrm{m}_{1}$ is very variable in $M i$ crotus nivalis mirhanreini SCHAEFER, and some specimens have the shape of the enamel loop quite similar to that in Microtus oeconomus (PALLAS). This similarity argues by no means in favour of the relationship of these forms since all other features show distinctly that these specimens belong to the species Microtus nivalis (MARTINS). This points however, to the necessity of great caution in describing new forms as often happens in paleontology - on the basis of one tooth or even on the basis of the whole dentition. In connection with this an outstanding dental anomaly should be pointed out 
in one specimen of Microtus nivalis mirhanreini SCHAEFER [fig. 4] which shows a very deep incision in the enamel of the inner loop of $\mathrm{m}^{2}$.

Both Carpathian forms of the snow vole present common features distinguishing them from specimens from the Alps. First of all the structure of the palate is the same in both, and differs from the typical form of this species. The bicoloured tail and its small length distinguishes both Carpathian forms from the Alpine ones.

Nevertheless I think that the Carpathian forms should not be considered as a separate species. These differences are not greater than those in the subspecies of the snow vole described from the Pyrenean, the Appenines and the Caucasus. Therefore I treat both Carpathian forms as two subspecies of Miorotus nivalis (MARTINS).

The Eastern Carpathian snow voles are more similar to the Alpine ones than the specimens from the Tatras. For example the colour of $M$. nivalis ulpius MHLER is similar to that of $M$. nivalis nivalis (MARTINS) and the colour of M. nivalis mirhanreini SCHAEFER is distinctly different. The structure of $\mathrm{m}_{1}$ in the Eastern Carpathian specimens does not present any major differences in comparison with the Alpine ones, but the same tooth in the Tatra specimens, being very variable, is usually of quite a different structure. Finally the length of the tail in the Alpine forms amounts to about 53 per cent of the body length (according to the measurements given by MrLLER, 1912), in those from the Czarnohora to 52 per cent and in those from the Tatras to 48 per cent. These facts show that $M$. nivalis ulpius MULER is more nearly related to the snow voles from the Alps than $M$. nivalis mirhanreini ScHAEFER. It may therefore be presumed that the colonization of the Carpathians by the voles came from the South East. We see a similar phenomenon in many plant and animal forms, e. g. rhododendrons occuring in the Alps and the Eastern Carpathians and not appearing in the Tatras. The fact that snow voles are absent in the Sudetes is also in accordance with this. 


\section{BIBLIOGRAPHY QUOTED}

1. Енгк G. 1941. Ergänzende Angaben zum Katalog der ungarisehen Säugetiere. Fragm. Faun. Hungar., Budapest, 4, 1, pp. 8-13.

2. Енік G. 1942. Eine neue Alpenwühlmaus, Miorotus (Chionomys) radnensis aus Siebenbürgen. Ann. Hist.-Nat. Mus. Nat. Hung., Pars Zool., Budapest, 34, pp. 18-30, 1 t, 5 ff.

3. Енгк G. 1949. Neue Angaben zur Kenntnis der Art Mierotus mirhanreini Schaefer. Sborn. Národ. Mus., Praha, 5, B, 4, pp. 81-86, 2 ff.

4. Ellerman J. R. 1941-1942. The families and genera of living rodents I - II. London, XIX + 689 pp., 189 ff., $\mathrm{XII}+690$ pp., $50 \mathrm{ff}$.

5. Ellerman J. R. and Morrison-Scotet T. C. S. 1951. Checklist of Palearctic and Indian mammals. London, $810 \mathrm{pp}$.

6. FUdAKowski J. 1933. Nowy ssak dla fauny Polski - polnik karpacki (Ohionomys ulpius Mrller). Ochr. Przyr., Kraków, 13, pp. $123-125,1 \mathrm{ff}$.

7. HaNzaK J. and Rosickx B. 1949. Nové poznatky o některych zástupcich řádu Insectivora a Rodentia na Slovensku. Sborn. Národ. Mus. Praha, 5, B, 4, pp. 1-77, 10 ff.

8. Kratochvil J. 1956. Hraboš sněžny tatranský Mierotus (Chionomys) nivalis mirhanreini ScHÄFER 1935. Práce Brněnske základny Čs. ak. věd, Brno, 28, 1,38 pp., $12 \mathrm{ff}$.

9. Lubicz-Niezabitowski E. 1933. Kluez do oznaezania zwierząt ssących Polski. 3 ed. Kraków, 124 pp., 19 ff.

10. Lubicz-Niezabitowski E. 1934. Bericht über die Säugetiere Polens und ihre geographische Verbreitung. Zeitschr. Säugetierk., Berlin, 9, pp. $188-197$.

11. Miller G. S. 1908. The recent voles of the Microtus nivalis group. Ann. Mag. Nat. Hist., London, 8 ser., 1, pp. 97-103.

12. Miller G. S. 1912. Catalogue of the mammals of Western Europe. London, XV + 1019 pp., $213 \mathrm{ff}$.

13. Монr E. 1950. Die freilebenden Nagetiere Deutsehlands. 2 ed. Jena, VI + 152 pp., $140 \mathrm{ff}$.

14. Mojsisovics von MoJsvar, 1897. Das Tierleben der österreichiseh-ungarischen Tiefebene. Wien (quoted in HANZAK and RosickY, 1949).

15. OGNEw S. I. 1950. Zweri SSSR i prileżaszezich stran, VII. MoskwaLeningrad, $706 \mathrm{pp}$., $347 \mathrm{ff}$., $15 \mathrm{~m} ., 10 \mathrm{tt}$.

16. Pohle H. 1932. Die Schneemaus (Chionomys) in den Karpathen nachgewiesen. Zeitsehr. Säugetierk., Berlin, 7, p. 259.

17. Rosicky B. and Kratochvil J. 1955. Drobni ssavei Tatranskeho narodniho parku. Ochr. Přír., Praha, 10, pp. 34-47, $12 \mathrm{ff}$.

18. SaGAN L. 1934. Polnik karpacki (Chionomys ulpius Mrleler). Oehr. Przyr., Kraków, 14, pp. 147-149, 2 ff.

19. SAGAN L. 1939. Ssaki (Mammalia) - Przyezynek do znajomośoi gryzoni Czarnohory. Rozpr. Spraw. Inst. Bad. Lasów Państw., Warszawa, A, 42, pp. $48-54$. 
20. Schaefer H. 1935. Studien an mitteleuropäischen Kleinsäuger, mit besonderer Berücksichtigung der Rassenbildung. Arch. Naturgeseh., N. F., Leipzig, 4, pp. 535-590, $20 \mathrm{ff}$.

21. Tatarinov K. A. 1954. K raspostraneniju i biołogii sneżnoj polewki w wostocznich Karpatach. Bjull. Moskov. Obszez. Ispit. Prir., Otdel. Biol., Moskwa, 59, 1, pp. 23-27, $1 \mathrm{f}$.

22. Winogradow B. S. and Argiropulo A. J. 1941, Opredelitel gryzunow. In: "Fauna SSSR" - Mlekopitajuszezije, Moskwa-Leningrad, 341 pp., $109 \mathrm{ff}$.

23. Winogradow B. S. and Gromow J. M. 1952. Gryzuny fauny SSSR. Moskwa-Leningrad, $296 \mathrm{pp}$., $132 \mathrm{ff}$.

\section{STRESZCZENIE}

W strefie alpejskiej i subalpejskiej Karpat występują dwa podgatunki polnika śnieżnego: Microtus nivalis ulpius MrLLER, 1908, w Karpatach Wschodnich i Microtus nivalis mirhanreini SCHAEFER, 1935, w Tatrach i Niżnich Tatrach. Opisany przez ЕнткА (1942) Microtus radnensis EHसK jest synonimem Miorotus nivalis ulpius MrLLER. Oba podgatunki znane były dotąd z niewielkich serii okazów. Zbadanie większych serii pozwoliło dokładniej uchwyeić zakres ich zmienności i wykazać ich wyraźne różnice. Oba podgatunki mają jednak szereg cech wspólnych, wyróżniających je od $M$. nivalis nivalis (Martins) z Alp. Podgafunek wschodnio-karpacki jest bardziej zbliżony do alpejskiego niż podgatunek tatrzański, co wskazuje na zasiedlenie Karpat przez te polniki od poludniowego wschodu. Niezwykła zmienność budowy $\mathrm{m}_{1} \mathrm{u}$ podgatunku M. nivalis mirhanreini SCHAEFER przy jednoczesnej stałośei takich eech jak ubarwienie, budowa podniebienia i inne, wskazuje na konieczność dużej ostrożności przy opieraniu opisów nowych form Microtinae jedynie na podstawie ksztaltu pętli szkliwa zębów trzonowych.

РЕЗЮМЕ

В альпийской и субальпийской зоне Карпат встречаются два подвида Miorotus nivalis (MARTINs): Miorotus nivalis ulpius MrLlen, 1908, в восточных Карпатах и Microtus nivalis mirhanreini SoHAEFER, 1935, в Татрах и Нижних Татрах. Опи- 
санный Әйком (1942) Microtus radnensis Енгк является синонимом Microtus nivalis ulpius MtLLeR. Оба подвида известны были до сих пор лишь в небольших сериях әкземпляров. Исследование больших серий позволило точно установить пределы их изменчивости и выяснить их существенные отличительные черты. Оба подвида обладают рядом общих признаков, отличающих их от $M$. nivalis nivalis (MARTINS) из Альп. Восточно-карпатский подвид приближается более к альпийскому, чем подвид из Татр. Это доказывает, что эти полевки проникли в Карпаты с юговостока. Необыкновенная изменчи вость строения $\mathrm{m}_{1}$ у подвида $M$. nivalis mirhanreini SCHAEFER, при одновременном постоянстве таких признаков, как окраска, строение неба и другие, указывает на необходимость большой осторожности при описывании новых форм Microtinae только на основании строения петлей эмали коренных зубов.

\section{BIBLIOTEKA}

Instytutu Biologii Ssaków

Polskiej Akademii Nauk

\section{$\mathrm{NrCz} .40 .2$}

Redaktor pracy - prof. dr A. Dehnel

Państwowe Wydawnictwo Naukowe - Warszawa 1957.

Nakład 1400+100 egz.-Oddano do składania 1. IX. 1956.-Podp. do drukú 22. II. 1957. Druk ukończono w marcu $1957 \mathrm{r}$.

Ar. wyd, 1,75 - druk, 1,5 Papier dmk, sat, III 80 g B 1 Nr Zam. 1088/56Cena ał 8,75

Wroclawska Drukarnia Naukowa 